\title{
The liability of the air carrier for damages and the state of health of the air passenger Accidents and Diseases (COVID-19)
}

\author{
ATTILA SIPOS \\ Honorary Professor, Faculty of Law, ELTE University, Egyetem tér 1-3, 1053 Budapest, Hungary
}

\section{ORIGINAL RESEARCH PAPER}

Received: August 15, 2020 • Revised manuscript received: October 15, 2020 • Accepted: October 27, 2020

Published online: June 8, 2021

(c) 2020 The Author(s)

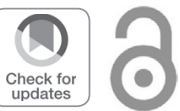

\section{ABSTRACT}

Viruses can be found everywhere, they are part of the real life of humanity. Air travel is the youngest form of geographical movement, which has become an attainable reality for everyone at the expense of extraordinarily huge efforts and sacrifices. The two realities collided at the end of 2019 and then on 11 March 2020 via the declaration of COVID-19 to be a world pandemic changing the world as known. This paper introduces these two realities and researches their legal relations.

Primarily, this paper seeks answers to the question whether pursuant to the Montreal Convention (1999) regulating the liability of the air carrier for damages an event or occurrence deriving from the disease or state of health of the passenger taking place during the operations of embarkation or disembarkation or on board the aircraft is deemed to be an accident. What extent of liability does the state of health of the passenger impose on the contracting parties pursuant to the rules of the Convention and according to legal practice?

An answer is provided by unfolding the conceptual elements of accident via legal cases. This introduces the significance of the internal regulations of the air carrier; the situation of passengers in need of special care; examines the existence of medical certificates and deals with the responsibility of the crew for the treatment of acute situations deriving from the state of health of the passenger (heart attack, thrombosis, virus infection etc.)

The answer is logical. Pursuant to the Convention, the event or occurrence deriving from the state of health of the passenger does not qualify as accident, consequently, the air carrier shall not liable. However, if in the facts of the concrete case a cause and effect relationship exists between the occurrence of the accident and the negligent conduct of the air carrier, the liability of the air carrier for damages can be established.

\footnotetext{
*Corresponding author. E-mail: sipos.attila@staff.elte.hu, siposa5@gmail.com
} 
The study introduces the system of conditions of the liability for damages in full detail, and the causal link producing an accident. The author makes recommendations for and outlines solutions in awareness that despite all real efforts, mankind has not learnt the lesson that the virus is in a winning position.

\section{KEYWORDS}

COVID-19, liability, air carrier, health, disease

\section{INTRODUCTION}

Nothing is as constant as change. Life may seem to be monotonous, nevertheless, every single day, events happen as never before. In aviation there are no two identical flights, each flight is performed in different surroundings and under dissimilar weather conditions, with diverse passenger and cargo loads, with numerous variants. What never changes, however, are the laws of physics and the significance of international civil aviation.

Aviation qualifies as public transport. Aviation industry with the production of modern technology and its utilisation shapes the future. Competition in the global world without the exploitation of the advantages and opportunities granted by modern civil aviation is impossible. One of the prominent advantages of air transport is that it is the fastest and safest form of transportation in the world. Undoubtedly, with respect to the coverage of great distances, air transport has the shortest time of carriage to any point of the Earth. That is why modern man takes advantage of the opportunities provided by aviation and measures distances not in kilometres or miles but in time. In scheduled civil international air traffic, the steady increase in the Revenue Passenger Kilometres (RPKs) ${ }^{1}$ despite all international conflicts and world crises ${ }^{2}$ was ascending and undiminished up to now.

Besides safety, the other most important aspect is the cheapness of the journey. The passenger is satisfied because at a reasonable price they may set off on a journey to their liking to any point of the world, while with good reason, they think that in the $21^{\text {st }}$ century infectious diseases do not imply such great danger for mankind as in previous decades. This has been known for a long time as an illusion. Air transport has a crucial role in the worldwide spread of diseases. Therefore, it is the responsibility and task of the specialised agency of the UN, the International Civil Aviation Organisation (ICAO) and other specialised international institutions to prevent the spread of infectious diseases via comprehensive measures. With a view to the prevention of the spread of infectious diseases, ICAO continually deliberates with international organisations ${ }^{3}$

\footnotetext{
${ }^{1}$ Revenue Passenger Kilometre (RPK): the kilometres covered by one paying passenger (for example, if the air carrier sells 177 tickets for the airplane with a capacity of carrying 200 passengers and the flight on route between Budapest - Paris (BUD-CDG) covers 1,250 km, then the flight accomplished 221.250 RPKs instead of 250,000 RPKs with full flight.

${ }^{2}$ The airlines from time to time are faced with minor-major critical situations beginning from the oil price explosion via terrorist attacks, natural catastrophes and economic world crises to the spread of contagious diseases. For instance, the Oil Crisis (1973), the Iraq-Iranian War (1980), the Gulf War (1991), the Asian Crisis (1998), the Terrorist attack on 11 September (2001), the SARS-virus (2003), the Economic World Crisis (2008), the Icelandic Eyjafjallajökull volcanic eruption (2010), the Ebola-virus (2014), the SARS-CoV-2-virus (2019).

${ }^{3}$ In 2016 ICAO launched the "Cooperative Arrangement for the Prevention and Management of Public Health Events in Civil Aviation" (CAPSCA) initiation. Within the framework of this programme ICAO regularly negotiates with the organisations concerned: WHO, FAO, UNWTO, IATA, ACI, UNDP, IFALPA, IOM, WFP. www.caspca.org (2020).
} 
designated to elaborate international health provisions to be applied at airports and on aircraft, including primarily the World Health Organisation (WHO). ${ }^{4}$ For the prevention of the spread of epidemics via air transport, the ICAO makes recommendations for its member states. The member states are responsible for the implementation of the recommendations. The basic obligation of the member states of ICAO is the prevention of the spread of the infection in all possible ways, in the interest of which all concerned authorities are involved, the member states make rules according to international recommendations, and then observe them.

The basic treaty guaranteeing comprehensive uniformity in international civil aviation is the Chicago Convention adopted on 7 December 1944, ${ }^{5}$ which, like 'a real Magna Charta,' ${ }^{6}$ as early as 75 years ago set a clear objective: 'the member states agree that they take effective measures to prevent the spread by means of air navigation of cholera, typhus (epidemic), smallpox, yellow fever, plague and such other communicable diseases as the contracting States shall from time to time decide to designate' (Article 14).

Of course, the member states need to cope diseases enumerated under the Chicago Convention, but with all the infectious diseases which medicine considers to be apt according to its features to spread worldwide. They include an array of diseases unfamiliar in 1944 appearing as a novelty such as pneumonia of type A, avian influenza and the Ebola-virus.

$>$ In 2003 a mysterious new disease, the Serious Acute Respiratory Syndrome (SARS) under its familiar name the pneumonia of type ' $A$ ' created a global panic worldwide, making a great impact on international civil aviation. The ICAO and the WHO rapidly reacted and made comprehensive recommendations for the member states. ${ }^{7}$ The member states were obligated to check the passengers more strictly at airports in the countries concerned by the epidemic:

-the persons producing the symptoms of the disease were not permitted to travel despite their valid air tickets;

-preceding embarkation the passengers had to be informed about the disease;

-a further health screening of the passengers arriving from infected places had to be carried out;

-the crew had to be trained to treat and separate the patient with SARS symptoms on board;

-the ground staff was trained to welcome the aircraft carrying passengers infected with the SARS virus and to sterilise the board efficiently.

${ }^{4}$ Paragraph E of Chapter 8 of Annex 9 to the Chicago Convention, Simplifications, $15^{\text {th }}$ ed., deals with the implementation of international healthcare rules and other provisions determined by WHO. 2017. (Points 8.12-15, recommendation 8.15.1, 8-3).

${ }^{5}$ The Chicago Convention on International Civil Aviation adopted on 7 December, 1944. Since 1994 in each year $7^{\text {th }}$ of December has been the World Day of international civil aviation, on which the member states decided at the $33^{\text {rd }}$ General Assembly of ICAO (1992). This initiation was acknowledged officially by the member states at the $75^{\text {th }}$ General Assembly of the UN. ICAO A-29. 1.; UN A/RES/51/33, 17 January, 1997.

${ }^{6}$ Kotaite (2013) 43.

${ }^{7}$ Singh (2006) $1-7 ; 35^{\text {th }}$ General Assembly of ICAO, Decision A35-12. (2004). 
$\triangleright$ In 2005, a new infectious disease, the avian influenza (H5N1) considered the most dangerous and apt to trigger a world pandemic demanded victims, which faced civil air transport with a new challenge. Upon the recommendation of the WHO the passengers needed to be preliminarily informed about the health risks of the flight, while at the airports the delegated healthcare staff asked loaded questions in order to discover the disease and they measured body temperature with heat cameras. At the airports a special premise was designated for persons believed to be vectors and for the case of the breakout of the epidemic ICAO and WHO recommended the immediate closure of the airport. $^{8}$

$>$ In 2009 the virus of the swine influenza (2009); the Middle Eastern Respiratory Corona virus (MERS-Cov, 2012); a novel virus of the avian influenza (H7N9, 2013) and the WesternAfrican Ebola-virus (EVD, 2014) all created victims all over the world. In the rapid spread of these viruses and the prevention of the evolution of world pandemic, air transport had an unarguably prominent role. The Ebola-virus (2014) is a good example of the successful stemming of the rapid spread of the virus. ${ }^{9}$ Although the air passenger infected with the Ebola-virus posed a minimal danger for other passengers, nevertheless, the mere presence of the infected person among the passengers raised serious concern. The Ebola-virus spread by blood and bodily fluids, not via inhaling and droplet infection. Therefore, the infected person does not imply danger for the neighbouring passenger. The common use of the toilet of the aircraft may undoubtedly entail risks. In such a critical period, a lot of people desisted from their journey, since the serious panic triggered by the heavily coughing passenger, who called out saying 'I have come from Africa, but I was only joking' (which could be a criminal legal facts of the case) could be outdone only by a passenger really infected with the Ebola or other virus on board the plane. ${ }^{10}$

SARS and the Middle-Eastern Respiratory Syndrome (MERS-Cov) were corona viruses, thus, it was not a novelty in December 2019 that mankind was faced with the SARS-CoV-2, a much stronger virus causing the COVID-19 disease consisting in grave pneumonia and complications. While the events with global effect slowed down and momentarily stopped the air transport industry, the COVID-19 disease caused incalculable damages managed to completely paralyse the airports formerly with record-breaking traffic and literally floored the passenger transport branch of international civil aviation. This current state of emergency not only due to its effect, but by reason of its systemic regulatory challenges. This does not bear a likeness to the situation related to other previous virus outbreaks, because limits could be set during their initial phase and isolation established in time. Although professional steps were taken after each epidemic event, mankind did not learn the lessons [just as in case the Human Immune-deficiency Virus (HIV)] for a long time.

\footnotetext{
${ }^{8}$ ICAO Report by Chief, Aviation Medicine Section, to the meeting at the WHO on avian influenza and human pandemic influenza. ICAO Secretary General, SG 1862/05 AN5/24 (2005); Simplifications 2.4. of Annex 9 of the Chicago Convention.

${ }^{9}$ Unfortunately, the Ebola-virus in an isolated manner, but these days still demands victims in Africa. WHO - Ebola virus disease - Democratic Republic of the Congo. Disease outbreak news (2020).

${ }^{10}$ Abeyratne (2014).
} 
The Hawaii State Healthcare Department of the United States announced in June 1994 that a 32year-old Korean woman died of tuberculosis. Before the diagnosis, the victim had flown from Honolulu (HNL) via flight of nearly $8 \mathrm{~h}$ to Chicago (ORD), then from there to Baltimore (BWI). She finally returned, after one month, back to Honolulu. The investigation of the authority revealed that during the journey the woman could have infected several passengers. Later the passengers were symptom-free but the investigation clarified several real problems. During the journey, the passenger had met 925 persons on board the aircraft, which gave rise to concern because the bacterium of the multi-resistant tuberculosis (MDR-TB) spreads quietly, insidiously, primarily via droplet infection (coughing, speaking, sneezing etc.) in the air. ${ }^{11}$ The WHO informed the industrial performers about the investigations, the character of the risk and the tasks in a publication. ${ }^{12}$ The air transport industry did not react to the prevalent danger uniformly, in spite of the fact that according to the WHO if the multi-resistant tuberculosis (MDR-TB) gains ground, it is unlikely that it can be stopped.

The COVID-19 launched the complex and comprehensive process of the current change. One of the most important consequences of this process is that the much-expected paradigm shift ensues unavoidably in civil aviation. We are on the threshold of a new era. Before a new era, bringing crowdedness deriving from obstinate competition on the earth and in the air.

\section{THE AIR PASSENGER AND THE MONTREAL CONVENTION (1999)}

Since the internationalisation of aviation, the passenger has been exposed to air carriers. One of the main reasons for this is that the air carrier has responsibility for damages, which is justified by the dangerous operation character of air transport and the vulnerable situation of passengers upon their transportation. Initially, the law-maker counterbalanced this burden under the Warsaw Convention (1929) ${ }^{13}$ by limiting the amount of the indemnification of damages in case of accidents suffered by the passenger in order to alleviate the situation of the air carrier. The limitation of the liability for damages is an institution just like many others adopted from maritime law. ${ }^{14}$ Its introduction was justified by the financial protection of air carriers, since upon the supervention of grave accidents, the air carriers became obligated to indemnify damages to such an extent that it plunged them into financially difficult, in extreme cases into critical situation. Therefore, one of the main performers of the air transport industry, the airlines needed proper provision of their liability for damages, its regulatory protection. Aviation is a capital-intensive, economically risky activity. Owing to the sharpened market competition a

\footnotetext{
${ }^{11}$ Kenyon et al. (1996) 334:933-8.; Global Plan to End TB: 2018-2022 (2019).

${ }^{12}$ The WHO presents 7 cases in its report released 20 years ago, according to which the spread of the virus happened or may have happened on board. Tuberculosis and air travel: Guidelines for prevention and control. Communicable Diseases Cluster (1998) Annex 1. 35-37.

${ }^{13}$ Article 22 of Chapter III. on Liability of the Air Carrier of the Warsaw Convention for the Unification of Certain Rules relating to International Carriage by Air (1929).

${ }^{14}$ For example, the registration of aircraft; the (peaceful) innocent passage; the 8 . and 9. commercial rights of cabotage; the freedom of traffic over high seas; the licensing procedures and administrative requirements. Sipos (2018) 29., 36-37., 54., 104., 128-29., 281., 312.
} 
large part of the airlines became financially vulnerable and their profit-making activity has remained low or showed a deficit for decades in the passenger transportation segment.

The strengthening of passenger rights as a consequence of the liberalisation of markets coincided with an increasing number of client-focused defensive measures being taken. The lawful fulfilment of rigorous obligations implied great, primarily financial and administrative burdens for the air carriers. The peak of the international strengthening of passenger rights consisted in the making of the Montreal Convention for the Unification of Certain Rules for International Carriage by Air, ${ }^{15}$ which replaced the Warsaw Convention and its amendments. ${ }^{16}$ Undoubtedly, the new Montreal Convention (hereinafter: Convention) entailed a paradigm shift. The law-maker took sides with the consumers vis-a-vis the financially strengthened ${ }^{17}$ and competent air carriers. It can be exaggerated that the passenger became the 'master'. ${ }^{18}$ The protection of the clients was so much foregrounded that upon the drafting of the Convention the following remark was made not accidentally: 'the solicitors of the aggrieved parties will be really pleased with the Convention.' ${ }^{\text {, }}$ The passenger has been placed in a much more advantageous position vis-a-vis the air carrier obligated to assume unlimited liability upon the occurrence of an accident.

The principal objective of the Convention is unification, the harmonisation of regulations and the elimination of conflicts of law. This guarantees that the claim for damages of the harmed passenger or consignor is adjudged on the basis of the same rules all over the world. The judgement is independent of the citizenship of the passenger, the place of causing the damage, the competent court, the condition of health of the passenger and the price of the air ticket itself. The liability of the air carrier for damages is maintained in case of free or extremely low-priced air tickets as well. Liability cannot be precluded and it is not admissible to unilaterally decrease the lawfully due amount of indemnification with reference to gratuitousness or cheapness of the air ticket or refuse the claim of the aggrieved passenger under such title. The persons participating in the journey in contractual relationship covered by the personal scope of the Convention have equal rights from the point of view of liability for damages and are insured equally independently of the fact whether they were travelling in second or first class. ${ }^{20}$ According to the principle of equal treatment, the law does not distinguish industrial business models (traditional and discount airlines), even if there are really considerable differences

\footnotetext{
${ }^{15}$ The Montreal Convention took effect on 4 November, 2003 and set off on its "conquering" journey. Namely, the Convention shall prevail over all other rules relating to international carriage by air (Article 55). So far the Convention has been ratified by 137 states. Convention for the Unification of Certain Rules for International Carriage by Air (MC 1999).; ICAO Doc 9740.; www.icao.int/secretariat/legal/List/Parties/Mt199 (15/10/2020).

${ }^{16}$ On the promulgation of the Montreal Protocol no. 4 signed on 25 September, 1975 in Montreal on the amendment of the Convention for the Unification of Certain Rules relating to International Carriage by Air signed in Warsaw on 12 October, 1929 as amended by the Protocol signed in The Hague on 28 September, 1955.

${ }^{17}$ According to the report by IATA between 2004-2011 the airlines realised profits of 4.1 per cent on average, which is extremely low in comparison with the profitability of other industries. After 2015 until the end 2019 the IATA member airlines realised higher profits, they made profits on average above 8 per cent.Pearce, (2013) 18.; IATA Annual Review (2019) 8 .

${ }^{18}$ Caplan (1999) 93.

${ }^{19}$ Whalen (2000) no. 1. 15.

${ }^{20}$ The airlines obligatorily maintain insurance for the coverage of the amount of indemnification of every passenger (Article 50).
} 
between them. All passengers and consignors, if they sustain damage and the liability of the air carrier, is established pursuant to the Convention, will receive equal treatment and uniform judgement.

The law-maker has always attended to the resolution of tension between the tortfeasor and the aggrieved party, to the proportionate balance of their interests. It markedly protects the interests of clients participating in international carriage by air. This new system does not permit the passenger to seek the court headlong with all presumed or real injuries and boundlessly, in the hope of higher indemnification, sue the air carrier with reference to its aforethought inappropriate activity, mostly because it caused accident owing to the negligence or at least to the deliberate carelessness of the aircraft commander proceeding in the scope of their tasks. ${ }^{21}$ Several legal institutions protect the air carrier, ${ }^{22}$ but it is also telling that the liability of the air carrier for damages may be established in a system of requirements in which at least 20 conjunctive conditions need to be fulfilled. ${ }^{23}$

In this complicated system, the present study seeks answer to the question whether pursuant to the Convention an event or occurrence deriving from the disease or the state of health of the passenger qualifies as an accident and according to the rules of the Convention and practice what responsibility the state of health of the air passenger imposes on the contracting parties.

\section{ACCIDENTS}

Pursuant to the Convention, the establishment of the liability of the air carrier requires the joint fulfilment of the conjunctive conditions:

1. the occurrence of an accident; and

2. the accident incurs the death or the bodily injury of the passenger; and

3. the accident happens on board the aircraft or during the operations of embarkation or disembarkation [Article 17 (1)].

If one condition or the conceptual element of a condition is missing, the air carrier shall not be liable, therefore, the determination of the conceptual elements of the accident is important.

\subsection{The first condition: an accident happens}

Minor or major accidents do happen during the journey several times, but one which substantiates the liability of the air carrier only rarely occurs. Its reason is that an accident is exclusively one, which the Convention qualifies as such. The generally acknowledged concept of

\footnotetext{
${ }^{21}$ However, in case of the act or negligence of the employees and agents it needs to be proved that they proceeded in the scope of their task. Article 25 of Chapter III. of the Warsaw Convention.

${ }^{22}$ For example, the institution of the so-called exclusive remedy (Article 29), the two-step system of unlimited liability (Article 21), the simplification of documentation of carriage (Articles 3-11), the conceptual elements of accident (Article 17).

${ }^{23}$ Tompkins (2001).
} 
the accident has been shaped by supplementary legal cases establishing legal practice to be followed in the larger part of the world. ${ }^{24252627}$

I. In the lawsuit DeMarines versus KLM Royal Dutch Airlines ${ }^{24}$ the Supreme Court of the United States was the first to enlarge upon the elements and peculiar criteria of the concept of the accident in its judgement. Mrs. DeMarines during the flight felt an explosive pain in her head. Consequently, her speech became unintelligible and complete obtuseness came upon her. After this case, the state of health of the passenger considerably deteriorated, persistent disturbance of equilibrium emerged. In the action, the plaintiffs sought and explained the causes of bodily injury in the operation of the regulatory system of air pressure on the aircraft and the rapid decrease of pressure (dehermetisation). The experts of KLM proved in the lawsuit that all equipment of the aircraft operated normally and no fault occurred.

The court held the standpoint that 'an accident is an event, a physical circumstance, which contrarily to the usual course of events occurs unexpectedly.' If the event ensued on board the airplane is an expectable, regular occurrence, the case obviously cannot be treated as an accident. An accident only occurs if the occurrence or event is unexpected, unusual, or unforeseeable. The operational decrease of pressure on the aircraft is not unexpected or unusual, thus, it does not qualify as an accident.

II. In the lawsuit Air France versus Saks ${ }^{25}$ the passenger on the flight travelling between Paris (CDG) and Los Angeles (LAX) by reason of the change of cabin pressure suffered complete loss of hearing in her left ear. According to the passenger, the injury occurred because maintenance by the airline was careless and the badly set regulating system of air pressure on the airplane contributed to the occurrence of the irretrievable loss of hearing. The legal representatives of Air France lodged a counterclaim, thereby, as plaintiff demanded that the passenger having become a defendant (reus in exceptione fit actor ${ }^{26}$ proved that she had suffered an accident in relation to flying on the aircraft. The passenger could not prove this fact.

The case is simple but nevertheless historic. In the course of the interpretation of the law, the court ruled that the accident which caused the bodily injury of the passenger needs to be unexpected or irregular, external to the passenger. This new approach is essential since bodily injury does not arise in the regular course of flying as an inner reaction of the passenger, but owing to the accident, because the accident is the cause of the injury. ${ }^{27}$

\footnotetext{
${ }^{24}$ DeMarines v. KLM Royal Dutch Airlines (1978).

${ }^{25}$ Air France v. Valerie Hermien Saks (1985).

${ }^{26}$ If the accused (the defendant) counterpleads, in this respect (s)he becomes a plaintiff.

${ }^{27}$ Sakaria v. Trans World Airlines (1994).
} 
III. In the lawsuit Brandi Wallace versus Korean Air $^{28}$ Wallace, the plaintiff was the victim of sexual harassment on flight 61 of Korean Air (KE) on route from Seoul (ICN) to Los Angeles (LAX). In the lawsuit for damages filed against the airline, the action of the plaintiff was dismissed in the first instance. According to the ruling of the court, the crew did not commit an act or omission during the whole time of the journey, which could substantiate the occurrence of an accident in relation to the operation of the aircraft and the event does not qualify as 'a characteristic risk factor of flying. However, the Supreme Court in its binding ruling established the occurrence of an accident with respect to the extraordinary circumstances of the case because the negligent conduct of the crew was eventually proved in the lawsuit.

Despite this the reasoning of the ruling in the first instance became a further stage of the interpretation of the law. On this basis the act, the assault (fight, slander or in this case, harassment) of the passenger vis-a-vis another passenger does not qualify as an accident, because these acts do not qualify as the characteristic risk factors of flying.

IV. The lawsuit Husain versus Olympic Airways ${ }^{29}$ further expanded the conceptual scope of accident determined in the previous legal case and it was enriched by a further essential phrase and thereby, it was completed. Dr. Abid Hanson, a 52-year-old passenger on board the flight travelling from Athens (ATH) to New York (JFK) had an asthma attack and died of the great amount of secondary cigarette smoke. The wife of the victim, Mrs. Husain mentioned that her husband received a seat in the non-smoking part of the tourist class, but it was only three rows away from the smoking section. With respect to the poor state of health of her husband, Mrs. Husain requested the flight-attendants three times to provide a seat for her husband further away from the smoking section, however, her request was rejected on each occasion with reference to the fullness of the airplane. In fact, there were 11 free seats on the flight and 28 seats were occupied by airline employees with open tickets, thus, there was opportunity for changing the seating of the passenger. The state of health of the passenger allergic to cigarette smoke was exacerbated by his asthma attack and his life, despite the medicinal help on board, could not be saved.

The court in its ruling obligated the airline to pay a large amount of indemnification. According to the court, the negative behaviour of the flight-attendant was contrary to the internal regulations of the airline, furthermore, it breached the industrial prescriptions, which is not in compliance with the requirement of ordinary and expected operation. The plaintiff thought rightfully that the rejection of help on the part of the person who is trained to help and works on board mainly for this purpose, creates an unexpected situation extraneous to her, the passenger. In other words, in the causal chain leading to the accident, in its context the behaviour of the flight-attendant was a chain link, which indirectly contributed to the death of the passenger, thus, the accident ensued in relation to the activity of flying. In this ruling the court expanded the scope of the concept of accident. As a consequence, the accident may ensue not only owing to the irregular or unexpected occurrence in the operation of the aircraft, but it may ensue owing to the irregular or unexpected act of the crew.

3.1.1. The conceptual elements of the accident. On the basis of the exemplary legal cases (I-IV) according to the applier of the law an accident implies:

\footnotetext{
${ }^{28}$ Wallace v. Korean Air (1999).

${ }^{29}$ Husain v. Olympic Airways (2002).
} 


\section{$\triangleright$ an unexpected or unusual;}

$\triangleright$ unforeseeable event or occurrence;

$\triangleright$ related to the activity of flying (with the risk proceeding from it);

$\triangleright$ external to the passenger;

$\triangleright$ owing to which the claimant passenger: dies or gets bodily injured.

Legal practice does not qualify as an accident:

- tripping on a piece of hand-luggage protruding from the rows of aisle seats; ${ }^{30}$

- tumbling down or slipping on a pillow or blanket on the floor; ${ }^{31}$

- injuries, inconveniences caused by adjustable seats; ${ }^{32}$

- on board communication and imparting information in a language unfamiliar for the passenger; ${ }^{33}$

- downgrading the entitlement to travel (the leg of the passenger got swollen in the tourist class) ${ }^{34}$

- backache, sprain or strain owing to the packing of hand-luggage;

- problems deriving from catering, its substance or quality and the food allergy (the pathological immune system reaction) of the passenger; ${ }^{35}$

- any event or occurrence deriving from the disease or state of health of the passenger.

A lot of debates are provoked by injuries, which do not qualify as accidents, caused by objects falling from the overhead compartments on the passenger but it is difficult to adjudge them uniformly. ${ }^{36}$ Depending on the circumstances the court may rule that they are accidents. ${ }^{37}$ They are unanimously not accidents if the passenger injures himself or herself upon the opening of the compartment. ${ }^{38}$ It does not qualify as an accident either if the passenger does not follow the instructions of the crew. For instance, the passenger does not fasten their seat belt and gets injured upon a small braking. In this case the court dismisses the action of the injured passenger, since it is proved that the damage was incurred by the negligence of the passenger and 'the airline took all the necessary steps to prevent the damage.'

No accident occurred either when the passenger despite the display of the warning of fastened seatbelts failed to fasten herself and hastened to the still open door to wave. The passenger fell out of the plane since she did not notice that the passenger stairs had been removed by the ground staff. Pursuant to the Convention no accident happened in spite of the fact that the passenger broke her leg and was hospitalised. ${ }^{39}$ As opposed, if the crew directly or

\footnotetext{
${ }^{30}$ Sethy v. Malév Hungarian Airlines (2012).

${ }^{31}$ Vanderwall v. United Airlines (2015).

${ }^{32}$ Wipranikv. Air Canada (2007).

${ }^{33}$ Thibodeau v. Air Canada, (2014).

${ }^{34}$ David v. United Airlines (2016).

${ }^{35}$ Meliniak v. El Al Israeli Airlines (2017).

${ }^{36}$ Truitt (2015) no. 2.

${ }^{37}$ Maxwell v. Aer Lingus Ltd. (2000); Smith v. American Airlines, Inc (2009).

${ }^{38}$ Wright v. American Airlines Inc. (2010).

${ }^{39}$ Chutter v. KLM Royal Dutch Airlines (1955).
} 
indirectly contributes to the emergence of an unexpected and irregular event, for instance, if the flight-attendant serves plentiful alcohol several times (for reasons of flight safety, drinking alcohol is permitted only if it is served on board) to the passenger, who in inebriated state starts harassing the other passenger, the case falls under the conceptual scope of accident. ${ }^{40}$ In that case the crew unanimously did not observe the rigorous prescriptions, owing to the negligent conduct the act of the passenger is unlawful, which is in relation with the activity of flying. If one member of the crew performs their duty under the influence of alcohol, drugs or any other substance triggering stupefaction and this is proved in the course of the establishment of the facts of the case, beyond the criminal and labour legal consequences the court will establish the fact of an accident and the liability of the airline for damages in every case. From the viewpoint of the safety of air transport, the staff discharging crucial activity may not breach its obligations because thereby it readily gives rise to emergency. Unanimously, the accidents when the passengers get injured during a forced landing of the airplane (for instance, fuel runs out or the nose gear does not open) are related to the activity of flying.

\subsection{Second condition: an accident causes the death or bodily injury of the passenger}

A cause and effect relationship needs to exist between the accident and the death or bodily injury of the passenger. While death is unanimous, it means the end of human life, bodily injury provides opportunity for much broader interpretation. The meaning of bodily injury, its precise definition has prominent significance during the work of the applier of the law, since the relationship between bodily injury and mental injury is an important aspect.

Therefore, the question is to what extent bodily (physical) injury involves mental (emotional, psychic) injury.

Bodily injury means a tangible, apprehensible injury resulting in a change of the human body: when a bone breaks or a muscle is strained, a cut or bruised wound emerges etc... This unanimously proves the injury, the bodily injury caused by an accident. ${ }^{41}$ The ambiguity of the concept is many times consciously reinforced by the plaintiffs filing an action in order to improve their position so that the mental injuries affecting them are adjudged as physical, bodily injuries by the court. In its text, the Convention does not make such a distinction expressly but unanimously it provides opportunity for the assertion of rights by reason of bodily injuries. Psychic, emotional problems, fears, mental injuries, even behaviour problems or traumas (even if the journey takes place on an airplane attacked or hijacked by terrorists), if they do not involve direct bodily injury, shall not qualify as accidents.

Fear of flying (panic, stress or claustrophobia) or anxiety after a journey with a provenly infected patient (probing symptoms), or emotional shock do not fall under the term of bodily injury. For instance, the passenger, whose handbag containing medicine against panic attack had been stolen in the transit lounge and was faced with this fact on board the airplane, obviously got into a troubled mental state. Of course, she requested the crew to turn back, because taking her medicines brooked no delay. Several requests of the passenger were rejected the aircraft commander decided on take-off. The passenger lost control so the aircraft taxied back to its stand. After the swift 'arrival', the case was brought up for trial. It was established that the

\footnotetext{
${ }^{40}$ Tsevas v. Delta Airlines (1997); Tompkins (2010) 172.

${ }^{41}$ Uthuppan Jacob v. Korean Air Lines Co (2015).
} 
passenger had not suffered bodily injury, physical damage or internal organic lesion. According to the allegation of the passenger breathing difficulties and sleep disorders had emerged in relation with the case, in addition, her concentration capacity decreased. However, pursuant to the Convention these psychosomatic symptoms do not proceed from an accident, therefore, the action of the passenger was dismissed by the court. ${ }^{42}$

Travelling in itself is a significant factor in increasing stress. The mildest manifestations of psychic troubles related to travelling include phobias and abruptly strengthening panic reactions. During travelling all anxious sicknesses may easily intensify. Unstable mental state or starting psychosis may cause the commission of violent acts on board the airplane. Unrestrainable aggressivity evolving on the airplane or at the airport has multiple origins. The most frequent is alcohol, drugs or unstable mental state, but there are cases when socialised adults take leave of their senses. ${ }^{43}$ A situation may also arise when not only one passenger is, but a group or all of the passengers are conquered by panic. Such a case does not qualify as accident either.

In the lawsuit Eastern Airlines versus Floyd Marie ${ }^{44}$ the plaintiffs litigated since on route from Miami (MIA) to the Bahamas one engine out of the three ones stopped working by reason of an oil pressure problem. The airplane turned back to Miami, but meanwhile the other two engines stopped as well and consequently, the airplane lost altitude very rapidly. The captain notified the passengers that they would land in the ocean, however, during the emergency fall the three driving gears could be restarted, which was nothing short of miraculous. The pilot was celebrated as a hero by the passengers. Nevertheless, a group of the passengers took action against the airline. However, their claim was dismissed by the court, because mental injuries and psychic traumas in themselves not entailing bodily injury do not fall under the concept of an accident.

Mental and psychic injuries ensuant on board the aircraft or during the operations of embarking and disembarking do not qualify as accident if they derive from:

- technical failure (for example: forced landing, flight manoeuvres different from general);

- the unstable mental condition of the passenger;

- fights, threats, harassment by the passenger vis-à-vis the other passenger;

- assault or threat by a third person; or

- extreme weather conditions (high turbulence, storm, strike by lightening).

Damages resulting from injuries caused by fight among the passengers are not indemnified by the airline, because they have not arisen in relation to the activity of flying. The air carrier is liable to indemnify the damages deriving from bodily injuries if they have arisen in relation to the activity of flying. For instance, the liability of the air carrier may be established with respect to the fight by the passenger vis-à-vis the other passenger if a member of the crew, maybe only

\footnotetext{
${ }^{42}$ Turturo v. Continental Airlines (2001).

${ }^{43}$ Felkai (2010).

${ }^{44}$ Eastern Airlines v. Floyd Marie (1991).
} 
indirectly, but contributed to the evolution of causing damage (the fight), that is, the crew did not discharge their tasks in compliance with prescriptions, but jeopardized flight safety.

The law-maker lays emphasis exclusively on bodily injury. However, judicial practice is divided in case of bodily injury in void of a definition, since if injuries are related to one another, we cannot always draw a sharp boundary between bodily and mental injuries. National legal systems have been shaping the legal boundary between bodily injury and mental injury up to now, which the courts interpret depending on the developed character and the peculiar development of the national legal system. Although in legal practice the Convention is usually applicable only in case of bodily injury, in legal development it is increasingly perceivable that extreme cases such as psychic injury deriving from sexual harassment or terrorist acts ${ }^{45}$ committed on board or extreme weather conditions ${ }^{46}$ are treated as accidents by the applier of the law.

In the case Morris versus KLM Royal Dutch Airlines ${ }^{47}$ the young 15 -year-old female passenger on route from Kuala Lumpur (KUL) to Amsterdam (AMS) awakened on board feeling that the unknown man next to her was molesting her. The passenger immediately reported the case to the crew, who took the necessary steps. The passenger suffered grave trauma and of course, she promptly consulted a doctor. The doctor established that clinical depression had developed in his patient. In the first instance the action of the plaintiff was dismissed because pursuant to the Convention this act does not fall under the conceptual scope of accident. However, the British Supreme Court obligated the airline to pay full indemnification and remarked that although bodily injury pursuant to the Convention did not happen, the crime gave rise to a process leading to a lasting psychic trauma, which, in the active performance of everyday tasks, has entailed the deterioration of capabilities. It was established that within the conceptual scope of accident, the clause that the ensued event is a 'characteristic risk factor of flying' does not have to be taken into account at all times.

In these extreme, tragic cases Post Traumatic Deficiency Syndrome (PTDS) easily develops, and this psychic illness may entail bodily consequences, which falls under the conceptual scope of accident.

In the lawsuit Herman versus Trans World Airlines ${ }^{48}$ the aggrieved party took recourse to the court with a claim for damages by reason of insomnia, depression, loss of weight, nightmares, extreme anxiety as a consequence of terrorist action. Of the passengers of the plane Mrs. Edith Rosman, who was physically unhurt with her children, also lodged an action by reason of suffering several

\footnotetext{
${ }^{45}$ Husserl v. Swiss Air Transport Co. (1986).

${ }^{46}$ Spielberg v. American Airlines Inc. (2000).

${ }^{47}$ Morris v. KLM Royal Dutch Airlines (2000); Judgement of British Supreme Court of Judicature, case no. B3/2000/3820 (2001)

${ }^{48}$ Newman and Burrows (2013) Part I., Chapter 7. 60-61.; Herman v. Trans World Airlines, Inc. (1972).
} 
traumas. During the terrorist act, the passengers held in custody were exposed to considerable stress by reason of being closed, strong fluctuation of temperature, improper nutrition and hygienic circumstances. In the lawsuit Rosman versus Trans World Airlines ${ }^{49}$ just as in the Hermancase the Supreme Court established that mental terror and distress in themselves do not substantiate compensation pursuant to the Convention. This necessitates the proof of objective bodily injury assessable in itself, but if psychic injury directly entails bodily injury as in these cases happened, the air carrier shall be liable for damages. ${ }^{50}$

Terrorist attacks (hijacks and taking hostages) generally incur injuries and death, but even in these grave cases the establishment of the liability of the air carrier does not always happen. ${ }^{51}$ At the same time, if mental suffering or injury emerging during the flight entails bodily injury or organic damage and the causal relationship exists, the air carrier is liable for the emerged damages. This new direction has produced a lot of legal debates, which is capped by the fact that damages deriving from psychic injury are very difficult to calculate financially. This instantiates a new social expectation, in the case of mental injuries, psychic traumas developed under extreme circumstances the applier of the law should not be passive, should not interpret the statute literally or should not follow the normative legal practice by all means. Undoubtedly, the applier of the law who observes the law literally but breaches its spirit shall also injure the law. ${ }^{52}$

\subsection{The third condition: the accident takes place on board or during the operations of embarkation or disembarkation}

The distinction of operations is legally significant, since during embarkation and disembarkation the passenger is subject to the scope of the Convention, that is, the operation demonstrates when the liability of the air carrier commences and finishes. Prior to and posteriorly to these operations the passenger is at the airport, thus, for the legal problems occurring in these periods national law shall be guiding in void of a uniform international system of rules of liability for damages pertaining to airports. For instance, if the passenger falls in the parking lot of the airport, gets injured at the lifts or in the area of the terminal building or is assaulted not during the operations of embarkation or disembarkation.

It is generally recognised that the operation of embarkation commences when the passenger is put under the charge of the employee (agent) of the airline and follows their instructions. For instance, when the passenger ultimately heads for the boarding gate with the actual intent of embarkation or having finished waiting at the boarding gate answers the call of the airline employee by heading for the gate and joining the queue. ${ }^{53}$ The operation of disembarkation finishes when the passenger reaches the building of the airport and leaves surveillance by the

\footnotetext{
${ }^{49}$ Rosman v. Trans World Airlines, Inc. (1977).

${ }^{50}$ Barnett (1975), no. 1. 191-204.

${ }^{51}$ Lowenfeld (1992) 83-84.

${ }^{52} 88$ th legal principle of part Regula Iuris of the Liber Sextus Code, 1298. In: Pallas Nagylexikon, Pope Boniface VIII (1235-1303), an entry. Pallas, Budapest, 1893-97.

${ }^{53}$ Walsh v. Koninklijke Luchtvaart Maatschappij (KLM) (2011).
} 
airline, that is, the further the passenger gets from the aircraft, the more they lose the opportunity to make the airline liable for the occurrence of an accident pursuant to the Convention.

\section{THE STATE OF HEALTH OF THE PASSENGER}

On flights events deriving from some disease arise on a daily basis. This is not surprising since in times prior to the worldwide spread of the SARS-CoV-2 virus on average by far more than one million passengers were aloft in the air in every minute of the day. Daily the carriage of 12 million passengers, cargo worth 18.8 billion USD took place on 120,000 flights. ${ }^{54}$ Despite the high numbers, it is surprising that annually on average more than 1,000 passengers ${ }^{55}$ died on board an aircraft as a consequence of some cardiovascular unforeseen event (mainly heart attack or stroke.)

In the lawsuit Fülöp versus Malév Hungarian Airlines ${ }^{56}$ the plaintiff on flight 090 of Malév airline on route from Budapest (BUD) to New York (JFK) suffered a heart attack and in relation to this he got irrecoverable heart muscle lesion and his life could only be saved via building in a triple pacemaker by the doctors.

The airplane was flying over the British coastline when the passenger felt sharp pain in his chest. He knew that he was in huge trouble because 4 years earlier he had been in such a state, thus, he had concrete experience about the symptoms. There was a doctor among the passengers on the airplane, who took care of the patient and found his blood pressure in order therefore, he alleviated his complaints with painkiller. The patient felt better, however, during the journey precordial pains appeared several times. After consulting the doctor and the crew, the aircraft commander decided not to disrupt the journey. After landing the patient was immediately taken to hospital, where it was established that he had had a heart attack, therefore, a life-saving heart operation was implemented on him.

In its ruling the court established that a heart attack does not fall under the conceptual scope of an accident, because it did not arise in relation to flying and the crew of the flight took all the necessary steps that can be expected in such a situation, therefore, the liability of the airline could not be established in the case.

It is the aircraft commander who has an outstanding legal status among the crew, who, under his commandment, is authorised to make final decisions on each issue related to flight safety on board. ${ }^{57}$ The aircraft commander is responsible for the operation of the aircraft according to rules whether he navigates the airplane or not. Generally, the airplane is navigated by alternating pilots (one of them on route there, the other on route back) so that both of them remain in practice. The commander pilot is obligated in relation to the state of health of the passenger:

$\triangleright$ to attend to the provision of first aid to the person who has fallen ill or suffered an accident on board the aircraft, furthermore, if necessary and justified, land on the first suitable airport and transfer the patient to a healthcare organ for the purpose of expeditious medical care;

\footnotetext{
${ }^{54}$ Aviation Benefits Beyond Borders (2018) 7.

${ }^{55}$ Rabind (2011).

${ }^{56}$ Fülöp v. Malév Hungarian Airlines (2003).

${ }^{57}$ Chicago Convention, 2.4 of Chapter 2 of Annex 2 on the Rules of the Air.
} 
$\triangleright$ to take records of births, deaths, accidents and the related measures on board;

$>$ upon death on the aircraft to take care of the preservation of the belongings of the deceased person until transfer to the authority.

The commander pilot is authorised to depart from the rules of flight at any time, but only in case the departure is unconditionally necessary and justified in the interest of the maintenance of flight safety. Thus, they are authorised to make a decision, after weighing all circumstances of the case, on the disruption of the flight and on landing on the nearest airport. The captain may decide that the psychic or mental problems emerging in themselves not entailing the bodily injury of the passenger or the physic and behavioural disorders deriving from the disease of the passenger shall not entail the liability of the airline for damages.

In the case Rónai versus Delta Airlines ${ }^{58}$ the claim for damages of the plaintiff arose on a flight of Delta airline on route from Budapest (BUD) to New York (JFK), which was similar to the Fülöp versus Malév case. The distinction was that the passenger did not suffer an actual heart attack. According to the allegation of the plaintiff, he suffered irrecoverable bodily injuries and psychic trauma since rapid medical intervention was omitted due to the decision of the commander pilot not to disrupt the journey via forced landing. However, mental damages and psychic trauma do not fall under the conceptual scope of accident formulated under Article 17 of the Convention as the court expounded it in its ruling dismissing the action of the plaintiff.

The rules of the Convention do not prescribe liability for damages pertaining to the state of health of the passengers, since unexpected events related to the physical and mental condition of the passenger such as heart attack, asthma attack, pulmonary embolism, stroke, ${ }^{59}$ thrombosis etc. are not the characteristic risk factors of flying, they do not arise in relation to flying and are not extraneous to the passenger, thus, they do not qualify as accidents. Therefore, the scope of liability of the air carrier does not encompass the events or occurrences deriving from the disease or the state of health of the passenger.

The essential content of the former statement is well explained by the risk of Deep Vein Thrombosis (DVT) frequently occurring on long-haul flights. The journeys spanning continents are already performed by direct (non-stop) flights thanks to modern airplanes. During the many times 13-15 h flights the passengers are limited in their free movement, which incurs the risk of the development of deep vein thrombosis due to the lengthy sedentary position. The high external air pressure, the low humidity (15-20 p.c.) on board corresponding to the air above deserts and low cabin pressure produce a relative oxygen-deficient state (hypoxia) and that circumstance induces several complex biochemical changes in the lower limbs. ${ }^{60}$ Owing to several hours' sitting and constant vibration blood circulation in the legs slows down, in varicose veins the blood stagnates. The most endangered persons are the elderly, expectant mothers and

\footnotetext{
${ }^{58}$ Rónai v. Delta Airlines (2000).

${ }^{59}$ Singh v. Caribbean Airlines Ltd (2014).

${ }^{60}$ Sándor (2009).
} 
the patients suffering from cardiovascular diseases. In civil aviation related legal cases have proliferated in great numbers ${ }^{61}$ and have become familiar as a 'tourist class syndrome'. ${ }^{62}$

In the lawsuit D. Wrobel versus Air France ${ }^{63}$ the plaintiff travelled on route from Rome (FCO) through Paris (CDG) and San Francisco (SFO) to Portland (PDX). The travelling time on these flights is altogether $18.5 \mathrm{~h}$. The plaintiff had a stroke on route between CDG-SFO. The passenger D. Wrobel justified the emergence of the stroke by the journey being lengthier than planned (the flight really reached its destination delayed by $3 \mathrm{~h}$ ) and being limited in movement on board, therefore, he demanded indemnification by the airline with reference to moral and biological damages.

According to the court, it is undoubted that on long-haul flights the sedentary position for hours increases the risk of the evolution of diseases, but the current state of health, contingent alcoholic affectedness or the consumption of sedatives, similar occurrences in the past necessitating medical intervention and their complications may contribute to the occurrence of disorders. The court in Rome held that the passenger could not prove beyond doubt the cause-effect relationship between the suffered injury and the lengthier journey because of the delay, therefore, it dismissed the action with reference to its factually and legally ungrounded character. ${ }^{64}$

Deep vein thrombosis unanimously develops owing to lengthy and monotonous sitting but not in relation to the activity of flying. Nevertheless, if not the flight is the origin of the health problem, logically, it may not result in holding the air carrier liable. The air carrier is responsible for flight safety, while the air passenger is responsible for their own state of health. Only the passenger and their doctor can reassuringly decide how the flight may affect their state of health. The airline can warn the passenger of the importance of bodily movement, the dangers of motionless posture, to the publication of free on-board magazines available for everyone about special exercises to be done in sedentary position in order to minimise the risk. ${ }^{65}$

In such cases the defendants (the airlines) are globally in a favourable position. There are, however, situations and circumstances when the court makes a decision in favour of the plaintiff. $^{66}$ If the air passenger in fact can prove that for instance, the deep vein thrombosis is a consequence of the cramped, uncomfortable seats and the health risk has evolved in relation to the activity of flying, they have a chance that the court deems the facts of the case as an accident pursuant to the Convention and obligates the air carrier to pay indemnification. Related to the health problems of the passenger, the in-service crew of the airline can be held liable only if they did not conform to the international industrial prescriptions pertaining to first aid. ${ }^{67}$ It is important to highlight if the crew (short of medical knowledge) does not provide the most

\footnotetext{
${ }^{61}$ For example, Van Luin v. KLM (2002); McDonald v. Korean Air (2003); Rynne v. Lauda Air Luftfahrt Aktiengelsellschaft (2003) legal cases.

${ }^{62}$ Tompkins (2001). nos.4-5. 232.

${ }^{63}$ Wrobel v. Air France (2009).

${ }^{64}$ Guerreri (2010). no. 1.

${ }^{65} \mathrm{Hu}$ v. Air China Limited (2007).

${ }^{66}$ Ehlers (2004).

${ }^{67}$ ECAC Air Passenger Health Issues (2004).
} 
appropriate 'treatment' for the patient or the help does not promote the cure of the patient cannot refer to an accident. Even if the Automatic External Defibrillator (AED), which can save lives in case of the sudden stoppage of circulation, is missing from the aircraft owing to the fault of the air carrier is not deemed to be an accident. ${ }^{68}$ However, if the air carrier breaches international prescriptions and the internal rules and procedures based on them, it is qualified as an accident since the event is in cause-effect relationship with negligence related to the activity of flying.

In the case Safa versus Deutsche Lufthansa Aktiengesellschaft ${ }^{69}$ the passenger collapsed on board due to cardiac failure. After consultation with the doctors the crew continued the flight without disruption. After arrival the passenger was taken to hospital immediately, where the doctors established that the state of the passenger deteriorated considerably by reason of the delay. The court held that the crew conformed to international prescriptions and internal rules, therefore, the liability of the airline for damages is not sustained.

When during the flight a situation deriving from health develops, in a favourable case somebody among the passengers has a doctor's qualification, which implies great assistance to the patient and the crew. At the same time, the benevolent and professional help is futile if the state of the patient despite care deteriorates or in an extreme case the patient dies. In such a situation the case is generally brought up for a trial. Therefore, before the provision of assistance the doctor may request the crew of the airline to declare what insurance of liability for medical intervention the airline holds, in which the airline fully assumes the contingent damages deriving from medical activity. If the necessary and sufficient conditions of the provision of help do not exist, the airline does not hold such insurance or the doctor does not assume the legal risk, they may deny the provision of help as they are not obligated to participate in the rescue. It may also occur that the passenger, who has a medical background does not come forward when the crew is seeking a person with medical qualifications (doctor, nurse or paramedic), rather remains in incognito because they do not want to swell the number of those who, despite providing professional care, found themselves in a litigious procedure.

The air carriers are unanimously interested in the provision of appropriate and expeditious medical aid for the passengers during the flight. Therefore, they do their utmost in order not to plunge the doctor on board into a legally vulnerable situation. There are airlines which well in advance contact doctors as their prospective passengers and provide other benefits besides the full assumption of legal responsibility. ${ }^{70}$ It is more widespread that the doctor or the person with medical qualification providing help receives a travel voucher to be redeemed for the next journey or other travel allowance besides being guaranteed complete legal protection.

Nowadays there is a global medical emergency service, which provides 'phone-in' medical help to crew providing service all over the world. If the passenger or a member of the crew on the ground or in the air gets into trouble, a contracted company can be called where qualified

\footnotetext{
${ }^{68}$ Aziz v. Air India (2009).

${ }^{69}$ Safa v. Deutsche Lufthansa Aktiengesellschaft, Inc (2014).

${ }^{70}$ Doctor on Board program. www.lufthansa.com.
} 
doctors are waiting to provide professional advice and punctual instructions for taking care of the patient. If the commander pilot decides on a forced landing, the service provider arranges and prepares ambulance staff picks up the patient. This service can be subscribed. ${ }^{71}$

\subsection{Passengers with special needs}

The Convention does not mention passengers in need of special care. This is not needed as the personal scope of the Convention encompasses all persons ${ }^{72}$ in contractual relationship with the air carrier under civil law. With respect to the fact that air services need to serve all people's welfare, therefore, for the physically handicapped or people in need of special care for some other reason access to air transport needs to be granted irrespective of the fact whether the handicap originates in a deficiency, age, disease or another factor. The prioritisation of passenger rights necessitates that the air carrier provides its services for all passengers on equal terms.

Prior to the scheduled departure time, the passenger or the person paying for the carriage is obligated to inform the air carrier about the fact that the physically handicapped passenger or a serious patient with limited motility needs care on a stretcher; or use of an oxygen bottle for breathing or their physical size necessitates the booking of more than one seat. Information is important not only because this way the air carrier can carry the passenger in the best quality and in the most professional and safest way. This way the air carrier has the chance to limit, attach to conditions or eventually deny the carriage of these persons in compliance with flight safety regulations and technical prescriptions. The principal reason for this is that in case of emergency the rescue of passengers in need of special care requires extra effort, which cannot increase the risk of the implementation of the rescue operation disproportionately. For instance, the number of passengers in wheelchairs is limited depending on the type and capacity of the plane and on the internal regulations. The number of passengers requiring the booking of more than one seat because of their physical size is also limited and the placement of seeing-eye dogs of asthenopic passengers is possible only in a limited number. Expectant women after the $36^{\text {th }}$ week of pregnancy may travel only in possession of a separate permit and only if accompanied by a doctor. Infected patients may not travel or stay on board the aircraft at all. Air carriers specify these special, simultaneously obligatory rules in their internal regulations, the General Conditions of Carriage.

\footnotetext{
${ }^{71}$ Such service is provided by companies such as MedAire's, MedLink and Stat MD. Medical Emergencies - Guidance for Flight Crew. www.skybrary.aero/index.php/Medical_Emergencies_Guidance_for_Flight (2020).

${ }^{72}$ The scope of persons encompasses everyone on board the aircraft (or performing embarkation or disembarkation), furthermore, everyone who is in contractual relation pertaining to carriage with the air carrier, that is, who has an air ticket [Article 1 (1)]. Persons does not encompass special staff (pilots, flights attendants, in some cases the flight engineer or mechanic travelling on board indicated on the flight document or flight command) because for them the employment contract concluded with the air carrier is normative. Persons does not encompass those airline employees who are sitting among the passengers and have valid air tickets. The Convention does not pertain to stowaway passengers (free riders) because the contractual relationship between the parties is missing. The Convention is not applicable to minors coerced to travel either (for instance, abducted minors because of divorce; see Ko v. EVA Airways Corporation, 42 F. Supp. 3d 1296. February, 2012.), although s(he) has got an air ticket, but it was bought involuntarily. The personal scope of the Convention applies to gratuities: (free) carriages without remuneration. Danko (2012); Abeyratne (2017).
} 


\subsection{General Conditions of Carriage}

The detailed contractual conditions of the air passenger carriage contract concluded between the air carrier and the passenger not regulated under effective rules are specified under the General Conditions of Carriage. The provisions of the internal General Conditions of Carriage constitute a part of the contract between the air carrier and passenger. The internal regulations containing the conditions part of the contract is a not a norm. This is the service provision strategy preordained unilaterally by the air carrier for the purpose of the conclusion of several contracts via the imposition of a service framework, while the other party (the passenger) does not participate in the determination of the conditions part of the contract.

The airlines are obligated to draft the internal regulations with regard to international and European Union regulations, the prescriptions and recommendations of the International Air Transport Association (IATA), ${ }^{73}$ to national statutes and authority prescriptions subject to approval by the authority. The General Conditions of Carriage may not be contrary to statutes but otherwise the air carriers decide themselves, maybe departing from each other, what services under what conditions they provide for the passengers. ${ }^{74}$ For instance, for reasons of flight safety the air carrier may prohibit or limit the use of various electronic devices e.g., mobile phones, laptops, portable recording devices, portable radios, CD-players, electronic games, relay devices, radiocontrolled games. However, the use of hearing aids and pace-makers is permitted on airplanes.

The breach of obligations determined under the contract of carriage entails legal consequences. The air carrier is authorised to take measures deemed to be necessary if a passenger on board the aircraft behaves so that they

$\triangleright$ jeopardises the aircraft, the safety of persons and property on board or flight safety on the basis of the grounded judgement of the crew;

$\triangleright$ harasses the crew verbally or physically and impedes them in the discharge of their tasks;

$\triangleright$ does not comply with the instructions of the crew;

$\triangleright$ causes inconvenience or annoyance, damage or injury to the persons on board, incurs damage to the property on board.

A passenger is obligated to manifest behaviour in compliance with the instructions of airline employees during the complete carriage not only on board but also during embarkation and disembarkation. If the commander pilot forms the opinion that the behaviour of the passenger jeopardises flight safety, the safety of the passengers and the crew, it may deny the carriage of this passenger. Pursuant to the Tokyo Convention the aircraft commander is authorised to enforce measures restraining personal freedom vis-a-vis the passenger, of whom they presumes with good reason that they is about to commit or has committed an offence or an unlawful act on board the aircraft. ${ }^{75}$ The aircraft commander may instruct the members of the crew and may request but not instruct the passengers to provide even physical help to the enforcement of measures restraining personal freedom. ${ }^{76}$ In this case, the members of the crew or the passengers

\footnotetext{
${ }^{73}$ IATA Recommended Practice 1724 (2016).

${ }^{74}$ Sipos (2018) 310-11.

${ }^{75}$ Tokyo Convention on Offences and Certain Other Acts Committed on Board the Aircraft. Article 6 of Chapter III. on the Powers of the Aircraft Commander.

${ }^{76}$ Sedigh v. Delta Air Lines, Inc. (1994).
} 
may take preventive measures appropriate for the emerged situation without authorisation. Prevention is vital in aviation, therefore, already upon the commencement of the journey efficient measures are necessary because it is safer and cheaper to exclude the passenger on the ground, if circumstances require. The situation is not simple, the passenger does not share their personal motivation, sensitive data concerning their person e.g., state of health, pathological addiction or does not clearly indicate how they will react to unforeseeable events and situations.

\subsection{Medical certificate}

An air carrier cannot check the state of health of the passengers, therefore, it is necessary, besides the several measures already in place, to elaborate a rigorous system of requirements, which decreases the risk of boarding by infected persons. From the beginnings of air travel, air carriers, mainly in their internal regulations, have prohibited travelling by infected patients. However, the systemic control and documentation of this requirement have not been introduced, of course, now they will supervene. Notwithstanding, the idea is not novel. Passengers in need of special care, who are obligated to request their doctor's advice concerning the risk of their air travel. Precisely by reason of the risks hidden in the travel of such person, an air carrier reserves the right to demand a medical certificate issued (in compliance with the prescriptions of IATA and WHO) at least in English language concerning the transportability of the passenger, or, if necessary, accompaniment by a qualified doctor or nurse. The medical certificate has to contain unambiguously that on the given day(s) of the journey(s) the air travel of the passenger is risk-free or under what conditions it is risk-free and that the passenger may travel without accompaniment. The air carrier may deny the confirmation of the booking or the carriage for any of the following:

$\triangleright$ the passenger or their agent does not comply with any of the requirements determined by the air carrier;

$\triangleright$ the presented medical certificate is insufficient;

$\triangleright$ on the specific type of the airplane operated on the given route the conditions specified in the medical certificate are not available;

$\triangleright$ the transfer of the passenger cannot be solved to another flight.

So far as the passenger has requested medical advice or support, but does not comply with it during the journey, for the accident, bodily injury, impairment of health or its deterioration, eventually, for the death of the passenger the air carrier shall not be liable.

The employees of airports and airlines are obligated to act preventively and uniformly intervene vis-a-vis the spread of diseases in compliance with international and national health prescriptions. If the employees proceed according to rules, they cannot be held legally liable for events or damages deriving from the state of health of the passenger. Even if at the airport the screening of a really infected person was not feasible e.g., a certain medicine temporarily takes down the high temperature of the patient infected with the virus and this person boards the airplane. The employees of the airport do not have the qualification or practice to tell whether the passenger suffers from an infectious disease. The air carrier itself does not have precise information related to the state of health of the passenger (with the exception of the passenger in need of special care) and the staff cannot be expected to 'examine' the passengers professionally and to proceed depending on the 'medical findings' (constat) before the journey. This is not realistic. It is exclusively the passenger who knows what their state of health facilitates and to what extent they can undertake the risks incurred by the journey and the entailed responsibility. 
Since the state of health of the passenger is only known by the passenger, therefore, the responsibility is theirs and their doctor's. The air carrier could be liable for the damages deriving from the health problems of passengers if it could obligate each passenger to submit a medical aptitude document (conforming to international standards) $48 \mathrm{~h}$ before the journey. On the basis of medical certificates, the air carrier could decide unilaterally on whom and under what conditions it allows to board the plane. Obviously, this idea in practice seemed unfeasible for a long time regarding all passengers, however, these days it is quite realistic. Air carriers need to drive back the growing number of cases, primarily, when passengers in poor state of health venture on air travel irresponsibly or they undertake travelling with a disease, thereby, jeopardising others' safety and life. It is in the best interest of each air carrier that accidents should not happen, and if they do, it should not qualify as an accident pursuant to the Convention. If this situation emerges, national law will be directive.

\section{THE ROLE OF NATIONAL LAW}

Nation states have adopted prompt rules related to the treatment of COVID-19, which many times essentially differ from each other, therefore, the question arises to what extent national law has a role in the establishment of the liability of the air carrier for damages. The principal objective of the Convention is the unification of specific important rules of international air carriage. These major international private law rules function as collision norms, but also, from the viewpoint of the legal relation, they contain normative law as well as partly refer to or depend on domestic law. Thus, the Convention renders scope for national law, case-law and even for IATA industrial resolutions, since the law-maker cannot and may not unify all rules. Thus, the application of domestic law is necessary: directly e.g., in the establishment of the scope of competence, in the process of legal procedures and in the calculation of damages and deadlines ${ }^{77}$ and indirectly e.g., the Convention does not define major terms, therefore, their circumscription and the clarification of their conceptual elements devolves on the national application of the law.

It should be highlighted that, on an international level, there have been no uniform rules of liability for damages made with respect to major industrial performers such as international airports, aircraft manufacturers, air navigation service providers (ANSP). Therefore, the national statutes are applicable in legal disputes related to these areas. At the same time, the liability of air carriers is regulated on an international level by the Convention. If the Convention for some reason is not applicable, it is immediately replaced by the national law. At that time, the special and emphatic legal institution of the Convention: exclusive remedy (Article 29) should be taken into account. ${ }^{78}$ In differing national legal systems it is

\footnotetext{
${ }^{77}$ The provisions of the Convention below refer expressly to the national application of the law: $>$ The national law of the court having jurisdiction and proceeding in the case regulates procedural issues [Article 33 (4), and Article 45]. $\triangleright$ The action on the claim for damages may be brought within a period of two years, the method of calculating that period shall be determined by the law of the court seized of the case (Article 35).

${ }^{78}$ In the carriage of passengers, baggage and cargo any action for damages, however founded, whether under this Convention, or in contract or in tort or otherwise, can only be brought subject to the conditions and such limits of liability as are set out in this Convention, without prejudice to the question as to who are the persons who have the right to bring suit and what are their respective rights. The Montreal Convention, Article 29, The Basis of Claims.
} 
exclusivity that guarantees the primacy and the comprehensive enforcement of the Convention.

In the case Sidhu versus British Airways ${ }^{79}$ the flight on route from Kuala Lumpur (KUL) to London (LHR) landed on the international airport of Kuwait (KVI) in order to refuel. During refuelling, Iraqi armed men invaded the airport and held the passengers and the staff back. The passengers of the flight were transported to Baghdad where they were detained for a month. Later the armed men released the hostages, who travelled home safely. The plaintiff passenger contended in the lawsuit that the airline landed in a war-stricken zone and was or should have been aware that $4 \mathrm{~h}$ before landing, Iraq had started wartime operations. During being locked-up for a month, the passenger suffered grave psychic injuries which led to bodily injuries. The passenger got ill, developed eczema, lost a lot of weight and finally turned to the court.

The court, however, held that pursuant to the Convention no accident happened. Thus, the main question was not under what conditions and to what extent the psychic injury may be deemed as an accident pursuant to the provisions of the Convention, rather, the court sought an answer to the question: if the action of the plaintiff is unsubstantiated vis-a-vis the air carrier, vis- $a$ vis what party and under what law the passenger can enforce their claim for damages for the indemnification of the truly incurred damages.

The intent of the law-maker is unanimous. The liability of the air carrier for damages should be uniform and exclusive, superimposed over national legal systems. Exclusive remedy also serves the purpose that where law enforcement is inapplicable vis-a-vis the air carrier, the claimant should not have the right to sue the air carrier pursuant to national or any other law. ${ }^{80}$ That is, if the action cannot be adjudged pursuant to the Convention, the same action should be inadmissible vis-a-vis the air carrier pursuant to domestic or any other law.

The majority of courts renders this rule rigorous interpretation and according to acknowledged judicial practice the aggrieved party is ultimately deprived of the opportunity of indemnification vis-a-vis the air carrier if they cannot enforce their claim pursuant to the Convention in void of legal grounds. At the same time, in some places, primarily in SouthAmerican countries the rule of the Convention is interpreted permissively and this practice is followed scarcely. ${ }^{81}$ Notwithstanding, exclusivity does not imply that the passenger remains without the possibility of the assertion of their rights only because they cannot demand indemnification from the air carrier. The aggrieved party may file an action vis-a-vis the tortfeasor third party (generally the other passenger) in their own right under civil or criminal law pursuant to the rules of national law. The Convention requires exclusivity by emphasising its primacy. Its objective is clear: escaping conflicts between national legal systems, shaping the real opportunity for uniform intervention.

\footnotetext{
${ }^{79}$ Sidhu v. British Airways (1997). 2. p. 84.

${ }^{80}$ EL AL Israel Airlines Ltd. v. Tsui Yuan Tseng (1999).

${ }^{81}$ Wegter (2006). no. 2. 133-48.
} 


\section{SUMMARY}

The infection of other passengers by the patient infected with corona or other virus in itself does not qualify as accident. The reason for this is that infection these days is the most widespread risk factor, therefore, it is not an unexpected, unusual or unforeseen event or occurrence. Infection is part of life, as in a lifetime, everyone catches influenza or has been exposed to an infectious disease. Obviously, if a patient infected with a virus infects others on board or during embarkation, futile is all prevention (cleaning, separation) and there is a very slim chance to be proved. The passengers are not easy to be found posteriorly and it is time-consuming to withdraw the aircraft for thorough checking from traffic, the procedure requires immense effort e.g., the spread of tuberculosis on board the aircraft was checked by 30 experts, for nearly 8 months for $1,200 \mathrm{~h}^{82}$

Nevertheless, there can be situations in which the judge establishes an accident and the liability of the air carrier. This requires the existence of a cause-effect relationship between the occurrence of the accident and the negligence of the air carrier. Such risks can include the following situations:

$\triangleright$ the air carrier does not deny the carriage of the passenger manifesting COVID-19 symptoms upon the operation of embarkation or does not take cautionary steps to make sure that the passenger is free of symptoms;

$\triangleright$ the air carrier neglects to separate the passenger manifesting COVID-19 symptoms on board or in case of the already separated passenger the air carrier fails to wait till the arrival of medical help before the commencement of the operation of disembarkation;

$\triangleright$ despite a trustworthy notification the air carrier does not check the passengers to separate the infected passenger;

$\triangleright$ the air-conditioning equipment (the filtration system) of the aircraft does not work ${ }^{83}$ or is defective or during the ground stay of the aircraft it [the ground or the auxiliary power unit (APU)] is not switched on professionally. ${ }^{84}$

Many times, in real life, it is not possible to know for sure or at all who has infected someone with a virus, in the least on the airplane in a situation, in which people can be infected by touching objects. Obviously, if it is proved that the passenger caught the infection during the service of the airline, or the staff or the agent of the air carrier discharged their duties by breaching the industrial prescriptions, there is a chance to sue the airline. This, however, is not realistic, since the course of business requires that during epidemics beside the observation of

\footnotetext{
${ }^{82}$ Tuberculosis and air travel: Guidelines for prevention and control. Communicable Diseases Cluster. WHO/TB/98.256. 1998. Summary of seven investigations of possible M. Tuberculosis transmission on aircraft. Annex 1. p. 1.

${ }^{83}$ In the case Dias v. Transbrazil Airlines, Inc. 26. Avi. (CCH) 16, 048 (S.D.N.Y. 13 October, 1998) decided under the Warsaw Convention it was alleged that the passenger contracted pneumonia and later died. According to the Court the passenger who died from pneumonia she had contracted, was as a result of the poor quality of the aircraft cabin air during a flight from Brazil to USA (NYC). The poor quality of cabin air causing the passenger to develop a fatal respiratory disease. The Court held that this could constitute an "accident". The logic of this case might be made applicable in case of coronavirus infections while travelling by air.Prager et al. (2020).; Onianwa and Agbonze (2020).

${ }^{84}$ Coles (2020).
} 
extraordinarily rigorous rules and double safety, the utmost is done so that the hygienic circumstances of the passenger are the highest possible from embarkation to the end of disembarkation. $^{85}$

Infectious diseases spread as pandemics, especially the COVID-19 disease tie the cooperation of industrial performers even closer, ${ }^{86}$ especially of airlines, airports and ground services. The new regulation will be at least as strict as the numerous air transport security requirements introduced after 11 September, which will totally transform former travel habits. Although the system of rules of flight safety and security has been developing and taking shape for a long time, now a familiar, but unsettled area needs to be regulated comprehensively, with regard to changing and diverging national rules. National regulations, procedures determined and required by international organisations and approved by national air authorities have an important role. Retaining confidence will require constant care, which will entail more administrative and approval procedures as well as authority supervision and will make the journey more closed. New travel requirements minimising human contact such as keeping distance and compliance with that in all the phases of the journey: systemic checking and if necessary, the separation of passengers, the application of modern technology (biometric face recognition systems, procedures based on the scanning of the retina), the introduction of uniform testing, all of these ultimately decrease the liability of the air carrier. At the same time, the extra expenses obviously entailing an increase in the prices will be eventually paid, as usual, by the passenger.

With respect to the facts that in the rapid and efficient spread of viruses, air carriers have a responsible role, and that the passenger, many times thrusting forward their interest, generally misjudges or disregards their state of health, beyond the recommendations of international organisations the industrial performers in cooperation with each other need to introduce an internationally recognised test system, which assesses the state of health of the passenger and its risks. This examination system preceding the journey would include two stages: the presentation of a preliminary medical certificate (e.g. IATA Travel Pass, WTO Yellow Card, special passport) based on uniform requirements and upon arrival at the airport a rapid and efficient examination in a medical facility prior to embarkation. If despite all rigorous international requirements, controls and internal regulations owing to the imputable conduct of the air carrier or its agents the infected patient boards the airplane provably and infects other passengers or jeopardises other passengers' safety and lives by their presence, this circumstance substantiates the liability of the air carrier for damages.

Air transport is an activity involving increased danger both on the ground and in the air in all processes of operation. If the activity involving increased danger is done carelessly or sloppily, it may be foreseen that an accident, and consequently, significant damage may arise. Even the prevalence of a slight mistake may incur grave consequences. However, carrying out these activities may not be banned despite all risks and tragedies because of their social and national

\footnotetext{
${ }^{85}$ According to IATA with respect to the spread of infections on board flying is one of the safest means of transport. IATA Guidance for Cabin Operations During and Post Pandemic. $3^{\text {rd }}$ ed, (2020) $1-35$.

${ }^{86}$ The most important industrial performers of civil air transport are the airlines, the airports and the air navigation service providers, furthermore, states' authorities, aircraft manufacturers and travel and consignment service providers, and last but not least the passengers. In attendance to the activity of air transport insurance companies, aircraft lessors and ground service providing enterprises have important roles. Shearman (1992) 7.
} 
economic significance. The Romans stated that 'navigating is necessary, while living is not!' The saying is true today; the world has not changed.

\section{REFERENCES}

'Aviation Benefits Beyond Borders. Executive Summary' (2018) ATAG report 7.

'Global Plan to End TB: 2018-2022' Stop TB Partnership (Geneva 2019).

88th legal principle of part Regula Iuris of the Liber Sextus Code in: Pallas Nagylexikon, Pope Boniface VIII (1235-1303), an entry. (Pallas Budapest 1893-1897).

Abeyratne, R., 'The Ebola Virus and Aviation' (2014) August 08 Sri Lanka Guardian <http://www. srilankaguardian.org/2014/08/the-ebola-virus-and-aviation.html> accessed 03 November 2020.

Abeyratne, R., 'Aviation Trends in the New Millennium' in Transportation of Abducted Children. (Routledge 2017) Chapter 17.

Barnett, J. F., 'Case comment: Rosman versus Trans World Airlines Inc' (1975) 1 Brooklyn Journal of International Law, 191-204.

Chicago Convention, 2.4 of Chapter 2 of Annex 2 on the Rules of the Air.

Coles, P., 'COVID-19 Aviation: Liability Implications Arising from Coronavirus' (2020) Market Insight, Clyde \& Co. Asia Pacific <www.clydeco.com/en/insights/2020/02/coronavirus-2019> accessed 03 November 2020.

Convention for the Unification of Certain Rules for International Carriage by Air (MC 1999) ICAO Doc $9740<w w w . i c a o . i n t / s e c r e t a r i a t / l e g a l / L i s t / P a r t i e s / M t 199>$ accessed 03 November 2020.

Danko, M., 'Montreal Convention Does Not Apply To Crew Members' (2012) Aviation Law Monitor, 18 $<$ www.aviationlawmonitor.com> accessed 03 November 2020.

ECAC Air Passenger Health Issues. (2004) WG.

Ehlers, N. P., 'Aviation in Europe. A Multiple-Challenge Industry' (2004) Annals of Air and Space Law, 29. Felkai, P., 'Repülőtéri biztonság kontra betegbiztonság? A “sickurity” problémája' (Airport Safety versus Patient Safety. The Problem of Sickurity) (2010) 41 Orvosi Hetilap 1702-707.

Guerreri, G., 'Italian Court Denies Recovery for Cerebral Haemorrhage Following 18.5 Hour Aircraft Journey' (2010) 1 Air and Space Law $79-80$.

IATA Annual Review (2019) 8.

IATA Guidance for Cabin Operations During and Post Pandemic (2020) 3rd ed. 1-35.

IATA Recommended Practice 1724 'General Conditions of Carriage, Passenger Services Conference Resolutions Manual (PSCRM)' (2016) 37th ed.

Kenyon, T. A., Valway, S. E., Ihle, W. W., et al. 'Transmission of Multidrug-Resistant Myco Bacterium Tuberculosis during a Long Airplane Flight' (1996) New England Jounal of Medicine 334:933-38.

Kotaite, A., My Memoirs 50 years of International Diplomacy and Conciliation in Aviation (ICAO 2013). Liability of the Air Carrier of the Warsaw Convention for the Unification of Certain Rules relating to International Carriage by Air (1929) Chapter III, Article 22.

\footnotetext{
${ }^{87}$ Plutarch (46-119 A.C.), the Greek philosopher and biographer noted down the sentence of Pompeius Magnus (106-48 B.C.), the Roman commander, which became an adage: "Navigare necesse est, vivere non est necesse." The commander addressed the sailors who, after the unload of wheat, did not intend to sail out of the Sicilian port to the stormy sea. Which means that a genuine profession requires, beyond humility and reverence, superhuman sacrifices (for instance, the doctor goes to heal the infectious patient). Plutarch: Life of Pompey. 50.1.
} 
Lowenfeld, A. F., 'Liability of Airlines for Injury Caused by Terrorism' (1992) in Masson-Zwaan,T. (ed) Air and Space Law: De lege ferenda, Essays in Honour of Henri A. Wassenbergh. Dordrecht 83-84.

Newman, L. W., Burrows, M. 'Legal Remedies Available to Hijack Victims of TWA Flights 847 ' in Newman, L. W., Burrows, M. (eds), The Practice of International Litigation (2nd ed. New York 2013) Part I., Chapter 7. 60-61.

Onianwa, K. I., Agbonze, K. A., 'The Coronavirus (COVID-19) Pandemic - The Liability of Air Carriers' (2020) Ajumogobia \& Okeke Law Firm, <www.ajumogobiaokeke.com/associates/kelly-a-agbonze/> accessed 03 November 2020.

Pearce, B., 'Profitability and the Air Transport Value Chain' (2013) IATA Economics Briefing, No. 10, IATA 18.

Plutarch: Life of Pompey. 50.1.

Prager, S., Harding, J., Chapman, M. 'Covid-19 and the Aviation Industry: Turbulent times ahead?' (2020) 1 Chancery Lane, Lexology <www.lexology.com/library/detail.aspx> accessed 03 November 2020.

Rabind, C. A., 'Cardiac arrest in the skies' (2011) 8 Singapore Medical Journal 582-85.

Sándor, T., 'Utazási trombózis' (Travelling Thrombosis) (2009) 3. Orvosi Hetilap.

Shearman, P. Air Transport Strategic Issues in Planning \& Development (Old Tappan 1992).

Singh, J., 'Preparedness Planning of the Aviation Industry for a Pandemic Crisis Management' (2006) 35 Journal of Aviation Management 1-7.

Sipos, A. A nemzetközi polgári repülés joga (The Law of International Civil Aviation) (ELTE Eötvös Kiadó 2018).

Tokyo Convention on Offences and Certain Other Acts Committed on Board the Aircraft. Article 6 of Chapter III. on the Powers of the Aircraft Commander.

Tompkins, George N., Jr., 'On the Basis of the Lecture of a Solicitor from New York' (2001) Leiden IIASL.

Tompkins, George N., Jr., 'Deep Vein Thrombosis (DVT) and Air Carrier Liability. The Myth and the Law' (2001) 4-5 Air and Space Law 232.

Tompkins, G. N. Jr., Liability Rules Applicable to International Air Transportation as Developed by the Courts in the United States. Sexual and other Assaults of a Passenger (Wolters Kluwer 2010).

Truitt, R. D. 'Plain Talk about Plane Claims: An Air Carrier Claims Examiner's Handbook. Overhead Bins - A Hard Case' (2015) 2 Journal of Air Law and Commerce 449-470.

Tuberculosis and air travel 'Summary of seven investigations of possible M. Tuberculosis transmission on aircraft' in Guidelines for prevention and control. Communicable Diseases Cluster. (WHO/TB/98.256. 1998) Annex 1.1.

Wegter, J. J., 'The ECJ Decision of 10 January, 2006 on the Validity of Regulation 261/2004: Ignoring the Exclusivity of the Montreal Convention' (2006) 2. Air and Space Law 133-48.

Whalen, T. J. 'The New Warsaw Convention: The Montreal Convention' (2000) 1 Air and Space Law $12-26$.

\section{LEGAL MATERIALS}

Inc., US Court of Appeals Second Circuit 314 N.E. 2d 848, 1977.

Air France v. Valerie Hermien Saks, US Supreme Court Reports, 470 U.S. 392, 105 S.Ct. 1338, 84 L. Ed. 2d 289, 1985.

Aziz v. Air India, 658 F. Supp. 2d 1144, C.D. Cal., 2009.

Chutter v. KLM Royal Dutch Airlines, US District Court, 132 F. Supp. 611, 1955. 
David v. United Airlines, WL 1573423, C.D. Cal., 18 April, 2016.

DeMarines v. KLM Royal Dutch Airlines, 580 F. 2d 1193 (3 Fed. R. Evid. Serv. 5753) 1978.

Eastern Airlines v. Floyd Marie, Supreme Court reporter 499 U.S. 530, 113 L.Ed. 2d 569, No. 89-1598, April 17, 1991.

EL AL Israel Airlines Ltd. v. Tsui Yuan Tseng, US Court of Appeals for the Second Circuit, No. 97-475, 122 F. 3d, 1999.

Fülöp v. Malév Hungarian Airlines, 175 F. Supp. 2d 651 (S.D.N.Y.) 2001; WL 202958 (S.D.N.Y.) 2003.

Herman v. Trans World Airlines, Inc., Court case 40. App. D. 2d 850. 337 N.Y.S. 2d 827, 830 (NY AD 2 Dept.) 1972.

Hu v. Air China Limited, Judgment No. 399/2009, Tribunal of Busto Arsizio in Case No. 1118, 2007. Husain v. Olympic Airways, 316 F.3d 829 (9th Cir.) 2002.

Husserl v. Swiss Air Transport Co., 388 F. Supp. 1238 (S.D.N.Y.) 1975.; Borham v. Pan American World Airways, U.S. Dist. Lexis 28554 (S.D.N.Y.) 1986.

Maxwell v. Aer Lingus Ltd., 122 F. Supp. 2d 210, November, 2000.

McDonald v. Korean Air (Ontario Superior Court of Justice), Docket 29708, 2003.

Meliniak v. El Al Israeli Airlines, C.F. 26952-10-14. 2017.

Morris v. KLM Royal Dutch Airlines, UKHL 7, 2002; Judgement of British Supreme Court of Judicature, case no. B3/2000/3820, 17 May, 2001.

Rónai v. Delta Airlines, US District Court, Eastern District of N.Y. No. 99 CV 6793 (SJ). December 21, 2000. Rosman v. Trans World Airlines.

Rynne v. Lauda Air Luftfahrt Aktiengelsellschaft QDC 004 (01/5586) Boulton DCJ, 2003.

Sakaria v. Trans World Airlines, 8 F.3d 164, 170 (4th Cir. 1993), cert. denied 114S.Ct. 1835, 1994.

Sedigh v. Delta Air Lines, Inc., 850 F.Supp.197 (E.D.N.Y.) 1994.

Sethy v. Malév Hungarian Airlines, US District Court, 2d 2012.

Sidhu v. British Airways. Lloyd's Law Reports. 76. (1997). 2. p. 84.

Singh v. Caribbean Airlines Ltd., 36 Avi. 16,127 (S.D.Fl.) 2014.

Smith v. American Airlines, Inc., No. 09-02903 WHA, 2009 WL 3072449, 22 September, 2009.

Spielberg v. American Airlines Inc., United States District Court, S.D. New York, 105 F. Supp. 2d 280, 2000.

The Montreal Convention, Article 29, The Basis of Claims.

Thibodeau v. Air Canada, 2014 SCC 67, [2014] 3 S.C.R. 340.

Tsevas v. Delta Airlines, WL 767278 (N.D.III.) December, 1997.

Turturo v. Continental Airlines, 128 F. Supp. 2d 170 (S.D.N.Y.) 2001.

Uthuppan Jacob v. Korean Air Lines Co. Ltd., Case No. 14-11663, 11th Cir., 20 March, 2015.

Van Luin v. KLM (New South Wales) 1 DCLR, (NSW) 25, 2002.

Vanderwall v. United Airlines, Inc., F. Supp. 3d, 2015 WL 309094 (S.D. Fla.) January, 2015.

Wallace v. Korean Air, No. 98 Civ. 1039, 1999 WL 187213 (S.D.N.Y.), 1999.

Walsh v. Koninklijke Luchtvaart Maatschappij (KLM), 09-civ-01803 (RKE) N.V. (S.D.N.Y.) 2011.

Wipranik v. Air Canada, No. CV 06-3763 AHM, May 15, 2007.

Wright v. American Airlines Inc., WL 446077, 2010.

Wrobel v. Air France, Tribunal of Rome, 9th Civil Law Section, Decision No. 9153, 28 March 2009.

Open Access. This is an open-access article distributed under the terms of the Creative Commons Attribution 4.0 International License (https://creativecommons.org/licenses/by/4.0/), which permits unrestricted use, distribution, and reproduction in any medium, provided the original author and source are credited, a link to the CC License is provided, and changes - if any - are indicated. (SID_1) 